\title{
Synergicity of Triple Helix Creative Economy Model in Malang
}

\author{
${ }^{1}$ SRI MULJANINGSIH, ${ }^{2}$ MULTIFIAH, ${ }^{3}$ AJENG KARTIKA GALUH \\ ${ }^{123}$ Department of Economics, Faculty of Economics and Business, Brawijaya University \\ email: 1ningsih2006@yahoo.com; 2multifiah@ub.ac.id; 33ajenggaluh.akg@gmail.com
}

\begin{abstract}
The Triple Helix concept, the government-academics-business relationship, has been established in response to the 2005-2025 Creative Economy Long-term National Development Plan, especially in the mission of economic value creation of creative innovation. This study explores the factors influencing sinergicity of the triple helix model with SMEs' organic product in Malang as its object. This research was conducted with mixed methodology of FGD and survey. Validity and reliability test were performed based on the Cronbach's Alpha value and after being fulfilled, continue with analysis factor. The result of analysis creates 3 factors, namely: 1) variable of creative industry driver subject; 2) variable of organic product's Moslem businessmen characteristic; 3 ) variable of creative industry supporting. It concludes that there is a correlation among those variables, but its sinergicity is not optimally done yet. The finding shows that there is a concept of creative economy product innovation sinergicity of triple helix model modification of SMEs in Malang.
\end{abstract}

Keywords: Creative Economy, Sinergicity, Moslem SMEs

\section{Introduction}

The 2005-2025 Long-term National Development Plan's (RPJPN) vision is "The Indonesian nation with good quality of life and creativity in the world". Meanwhile, the mission is "Empowering Human Resources as the Key Capital of National Development". According to the 2013 creative economy report issued by UNESCO, the creative economy is one of the factors which is worth to be paid attention because it is able to encourage a development among other characterized by job creation improvement and export earning. In addition, Bocella and Salerno (2016) explained that creative economy sector has a tight relationship with the development of the local economy sector. Having viewed the importance of SMEs (Small and Mediumsized Enterprise) becoming the backbone of Indonesia's economy and creative economy in which its development also encourages creativity-based job creation, paying attention to SMEs engaging in creative economy sector is important to develop their business more and enhance job creation.

There are 14 subsectors categorized as creative industries, among others are advertising, architecture, art market, crafts, graphic design, fashion, film, video and photography, interactive games, music, performing arts, publishing and printing, computer services and software, radio and television, and research and development (Wirda, 2016). One of the products that have the potential to be developed in the field of creative economy is organic products. An organic product is a green product and gives added value. It needs creativity to produce a product which at the end will result in product innovation. Demand for the organic product at global level is enhancing nowadays. The Guardian reported that per August 2017, one of the biggest retailers in England, Tesco, experienced organic product selling enhancement by $15 \%$. Ocado, a courier service and logistics firm, also reported the enhancement of organic products reaching up to $16 \%$ in the last year-end. Waitrose, a supermarket selling organic products since 1980 , noted the average enhancement of organic product purchase increasing up to $5 \%$ from year to year. In addition, it is important to know that the improvement of organic

Received: December 27, 2017, Revision: March 29, 2018, Accepted: June 04, 2018

Print ISSN: 0215-8175; Online ISSN: 2303-2499. DOI: http://dx.doi.org/10.29313/mimbar.v34i1.3327.185-194

Accredited B based on the decree No.040/P/2014, valid on February, 18, 2014 until February, 18, 2019. Indexed by DOAJ, Sinta, IPI 
farming demand in the world reaches up to $15-20 \%$ per year with market share reaches up to the US $\$ 100$ million, but the market share which is able to be met only $0.5-2 \%$ from the overall agricultural products. According to the global organic trade, from the total number, Indonesia only contributes less than $1 \%$ in terms of organic food and beverage market share in 2015 with the total of market share reaches up to US $\$ 10$ million. Even though the market share is low, Indonesia is predicted to experience development increase of organic product by $9.4 \%$ in 2015 until 2020 .

Promising prospects in the future will become the cornerstone of Malang city to develop the creative economy sector. The 2005-2025 creative economy development of RPJPN is of course prepared in the local region including Malang. Malang is the second city in East Java province which its growth is relatively quick. Tri Bina Cita (Three Developments) as the Malang's branding has an image as a city of education, tourism, and industry. For that reason, Malang can be a creative and potential area. In addition, there are a lot of communities which care to the environment preservation, namely: farmer women group "Vigur Organik Buring", "Lily Group", and "Asta Karya Panca Wiguna". Those communities result in a green product in form of vegetables and the processed product, as well as nonorganic-based recycled craft product. Moslem SMEs in Malang is the member of those three communities. In order to develop the organic product, it needs help from various sides, namely: government, academics, and industry. In creative economy, the concept built is triple helix model. Triple Helix is a model with aims to describe and characterize interaction between government, industry, and university in the process of innovation, creativity and economic development (Natario et al. (2012) and Ranga \& Etzkowittz (2013)). It also refers to "The development of creative economy of Indonesia 2025" by the Ministry of Trade Republic Indonesia (2008). Creative economic development in Indonesia requires a symbiotic mutualism among three main actors: government, academician, and businessman (Fitriana, 2017).

The model shows unity among government, university, and industry. It means that there has to be a sinergicity among them, but it is still questioned. Therefore, the problem statement proposed for this research is: how is the sinergicity in the implementation of triple helix model in Moslem SMEs' organic product in Malang and what are the influencing factors? So the research's objective is: to find out factors influencing sinergicity in the implementation of triple helix model in Moslem SMEs' organic product in Malang.

Conceptually, sinergicity is an integrating process of many activities in order to achieve an optimal result (Mulyono, 2014). Sinergicity process was done through communication and coordination. According to Sofyandi and Gamiwa (2007) in Rahmawati el al. (2014), communication is an activity between the side giving and accepting stimulus or called responding side. On the other hand, Silalahi (2011) said that coordination is an integration of an activity between person and group to conduct something together. Moekijat (1994) in Rahmawati et al. (2014) proposed that there is a requirement to conduct coordination effectively. An effective coordination would be: a) performing direct relationship among individual or group; b) the first stage of coordination is easier to do at activity planning of decision making; c) coordination should be performed continuously among the arranged program; d) dynamic in nature which follows the environment condition both internally and externally; e) setting a goal of an activity clearly to be understandable by related side; f) arranging a simple organization chart; g) arranging job description to the authority and responsibility of all parties engaging in the activity; h) conducting communication effectively with related side; i) requiring good leadership soul to coordinate the activity.

The government has been establishing the 2015-2019 mid-term national development plan which contains nine agendas (NawaCita) in which three of them are 1) Building Indonesia from marginal area by strengthening region and rural in terms of unitary states; (2) Raising the community productivity and international market competitiveness; and (3) Realizing economic independence by driving domestic economy strategies sector. They, creative economy, entrepreneurship, and SMEs, are three fields having a fundamental role to realize those three national priorities agenda. Henry and Bruin (2011) stated that creative economy is part of a creative industry which is the wider spectrum. Creative industry term initially appeared in 1990 to describe all industry activities related to the creativity which at the end will result in intellectual property (Henry, in Henry and Bruin, 2011).

Triple Helix is a model aiming to 
describe and characterize the interaction between university, industry, and government in the process of innovation, creativity and also economic development (synthesis from Natario and de Almeida (2012), and Ranga \& Etzkowitz (2013). In order to protect SMEs engaging in the creative economy sector which is highly relatable to the innovation, creativity, and also development (which one of the characteristics is job creation), thus, the triple helix model is truly suitable for reference source to analyze development and innovation conducted by SMEs. Triple Helix model can also be functioned to systematically analyze featured pattern between university-industrygovernment interacting with each other. As the university is home for academics, an entrepreneur is part of industrial area, and government is the side which institutionally sets, then interaction relationship among those three can be seen in figure 1 (Ranga and Etzkowitz, 2013).

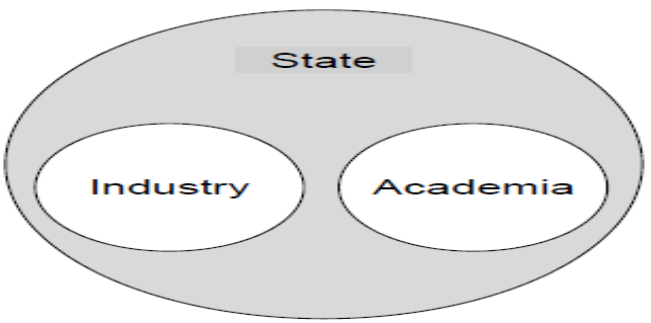

\section{Figure 1: Interaction ketiationships of Triple Helix Model}

Source: Etzkowitz and Leydesdorff in Ranga and Etzkowitz (2013)

Figure 1 indicates a relationship between government, industry, and university. It is also called static model in which government as the main role manages academics and industry but also limits their capacity to initiate and develop product innovations together with university's help (Ranga and Etzkowitz, 2013). Relationships style standing out between university-industry-government was observed from planning, performance, observation process, and evaluation from each agent which aims to develop creative economy products through innovation and creativity.

As mentioned earlier, Indonesia has the opportunity to develop the creative economic sector, especially organic products that refer to the green economy. The term of a green economy was initially triggered by United Nation (UN) in 2012 in the Rio+20 conferences (Barbie, 2012). Green economy is something which can raise welfare and social justice and at the same time significantly decreases environment risks and also existing ecological scarcity (UNEP in Pitkanen et al., 2016). Meanwhile, Loiseau (2016) stated that green economy is tightly related to the environmental dimension and also economy.

In the national scale, several countries develop strategy, policy, and program on green economy by which in the Asia level, South Korea is the leader (Loiseau, 2016). For Indonesia, Sukhdev et al. (2015) explained green economy model called Indonesia Green Economy Model (I-GEM) in which there are three indicators within, namely: GDP of the Poor, Green GDP, and Decent Green Jobs.

GDP of the poor is the whole rural and forest household income including cash earning and direct composition of forest products. Green GDP tightly related to the inclusive wealth which leads to sustainable development. Those two measures not only the visible economy luck of the ecosystem but also depreciation of natural capital like ecosystem degradation from year to year. While as the last variable, decent green jobs is a direct job created out of economic sector which relates to activities to reduce the bad impact on the environment from the existing economic activities. When we focus on the green GDP which tightly related to the inclusive wealth in which the last purpose is sustainable development, it was known that organic products or green product have a positive impact on the people and also help the increase of sustainable development (Rajasekaran and Gnanapandithan, 2013).

Based on the previous description, research's framework and the hypothesis are presented in Figure 2:

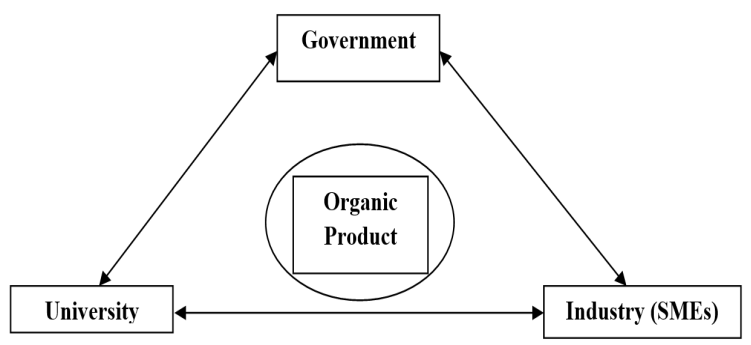

Figure 2. Triple Helix Model Implementation of Organic Product

Hypothesis of this research is "Sinergicity between three actors (Government, University, and Industry) in the Triple Helix economy creative through the implementation of Moslem SMEs' organic product in Malang". 


\section{Methodology of Research}

This research was conducted with mixed methodology of FGD and survey. Type of research is a quantitative approach that uses data in form of numbers or quantitative data using numbers as its data and analyzed using statistic test (Sugiyono, 2010). Quantitative approach usage emphasizes on theoretical test through research variable measurement with numbers aim to test the hypothesis. According to Creswell (2012), a qualitative method is an approach or search to explore and understand a central symptom. In order to understand the central symptoms, the researchers interviewed participant and respondent. Qualitative research is highly influenced by the view, though, and researchers' knowledge of the data collected from informant and will be interpreted by researchers. This mixed method approach is built on research's objective to know factors relating to each actor's role in the implementation of Triple-Helix Model to realize sinergicity as the effort of Moslem SMEs green organic product development in Malang.

The population of this research is SMEs in Malang and the sample representative of the population observed. Considering fund, time, energy, and accuracy in analyzing the data, this research used the sample. The sample-. that is, Moslem SMEs engaging in creative economy in forms of organic product--was collected through purposive sampling method. Criteria of respondents decision meeting one or all criteria fixed are: a) Government represented by the Head of Cooperation Board and Micro Enterprise and etc; b) University represented by the Head of Entrepreneurship Studies of Faculty of Economics and Business of Brawijaya University and etc; c) The head of a group of business of Moslem SMEs engaging in creative economy in form of organic processed and green recycled craft including Lily Group, Farmer Women Group "Vigur Organic", and "Sanggar Asta Karya Panca Wiguna". The number of respondents is 24, consisting of 2 government representatives, 5 university representatives, and 17 industry representatives.

\section{Quantitative Data Analysis}

Test of validity and reliability was performed. Validity of instruments item can be known by comparing the index of Pearson Product-Moment Correlation ( $r$ ) between the item score $(\mathrm{X})$ and relatable items score $(\mathrm{Y})$ with critical value at significance level (a). a value commonly used is $5 \%$. The formula to get $r$ is (Arikunto, 2006):

$$
r_{x}=\frac{N \sum X-\left(\sum X\right)\left(\sum Y\right)}{\sqrt{\left(N \sum X^{2}-\left(\sum X\right)^{2}\right)\left(N \sum Y^{2}-\left(\sum Y\right.\right.}}
$$

Description:

$r_{x y}=$ correlation score

$\mathrm{n}=$ the number of sample

$X=$ score of question item

$Y=$ score of total item

If the correlation value indicates Significance $<0.05$, it is said valid.

On the other hand, Sugiyono (2010) stated that reliable research instrument is the one which is used several times to measure the same object will produce the same result. The reliability test can be performed using statistic test of Cronbach's Alpha with formulation of:

Description:

$$
r_{11}=\left(\frac{k}{k-1}\right)\left(1-\frac{\sum \sigma_{b}^{2}}{\sigma_{t}^{2}}\right)
$$

$r_{11}=$ instrument reliability (Cronbach's Alpha coefficient)

$\mathrm{k}=$ the number of question item.

$\sigma_{\mathrm{b}}{ }^{2}=$ the number of item variant

$\sigma_{t}^{2}=$ total variants

The instrument can be categorized reliable if having reliability coefficient by 0.6 or more (Arikunto, 2006). On the other hand, Nunnaly (1994) in Ghozali (2011) stated that data can be said reliable if Cronbach's Alpha (a) $>0.70$.

The basic concept of factor analysis is used to reduce data or summarize variables, but it still contains the majority of information included in the original variables. Factor analysis will result in a new independent variable (free from each other), does not contain multicollinearity, and is a linear combination of original variables (Supranto, 2004). Score factor (new variable) as the original variable linear combination can be written as follow:

$\mathrm{F}_{\mathrm{i}}=\mathrm{W}_{\mathrm{i} 1} \mathrm{X}_{1}+\mathrm{W}_{\mathrm{i} 2} \mathrm{X}_{2}+\mathrm{W}_{\mathrm{i} 3} \mathrm{X}_{3}+\ldots \ldots+\mathrm{W}_{\mathrm{ik}} \mathrm{X}_{\mathrm{k}}$

Description:

$\mathrm{F}_{\mathrm{i}}=$ score factor (value) towards $\mathrm{i}$

$\mathrm{Wi}=$ coefficient factor towards $\mathrm{i}$

$\mathrm{k}=$ the number of original variables 
Table 1

Validity Result Test of Research Indicator

\begin{tabular}{|c|c|c|c|c|}
\hline No & Indicator & Correlation & Sig. & Description \\
\hline 1 & Individual as the main asset of creative industry & 0.854 & 0.000 & Valid \\
\hline 2 & Technology as a vehicle to realize individual creativity & 0.682 & 0.000 & Valid \\
\hline 3 & Resources (Natural Resources, land) & 0.686 & 0.000 & Valid \\
\hline 4 & Institution & 0.649 & 0.001 & Valid \\
\hline 5 & Financial Intermediary & 0.818 & 0.000 & Valid \\
\hline 6 & $\begin{array}{l}\text { The economy creative structure is protected by triple } \\
\text { helix interaction as the key factors of creative industry } \\
\text { driver. }\end{array}$ & 0.778 & 0.000 & Valid \\
\hline 7 & Intellectuals & 0.710 & 0.000 & Valid \\
\hline 8 & Business & 0.861 & 0.000 & Valid \\
\hline 9 & Government & 0.814 & 0.000 & Valid \\
\hline 10 & $\begin{array}{l}\text { Intellectuals, Business, and Government as the main } \\
\text { driver of creativity }\end{array}$ & 0.686 & 0.000 & Valid \\
\hline 11 & Tri Bina Cita as Malang Image & 0.824 & 0.000 & Valid \\
\hline 12 & Government support to creative industry & 0.875 & 0.000 & Valid \\
\hline 13 & $\begin{array}{l}\text { Entrepreneurs rooted in religion and free from "al- } \\
\text { ghayahtubarrirualwashilah" (the end justifies the } \\
\text { means) }\end{array}$ & 0.822 & 0.000 & Valid \\
\hline 14 & $\begin{array}{l}\text { An entrepreneur should be able to cultivate Islamic } \\
\text { work ethic }\end{array}$ & 0.638 & 0.001 & Valid \\
\hline 15 & A professional Moslem has to be Amanah & 0.832 & 0.000 & Valid \\
\hline 16 & $\begin{array}{l}\text { The properties of Amanah absolutely have to be held } \\
\text { by Moslem entrepreneur to avoid hurting others. }\end{array}$ & 0.618 & 0.002 & Valid \\
\hline 17 & $\begin{array}{l}\text { Developing and spreading creative culture to the } \\
\text { community around. }\end{array}$ & 0.973 & 0.000 & Valid \\
\hline
\end{tabular}

Statistics test used was Barlett test of sphericity. If this statistical test is significant, sample sufficiency assumption will be met so that factor analysis can be done.

\section{Qualitative Data Analysis}

Data analysis with qualitative method required data validity through triangulation method. Triangulation was done through time and source. Type of data collected was primary data. Furthermore, in order to know the role of Academics, Business, Government which is the agents of the triple-helix model to the Moslem SMEs' organic product in Malang, qualitative approach research with conducting Focus Group Discussion (FGD) and spreading questionnaire to the participant in the last session of FGD as its method was performed. There are 3 facilitators representing themselves from academics, entrepreneur, and government. The focus of the FGD was to find out agent role in the triple-helix model towards Moslem SMEs's organic product in Malang.

\section{Sinergicity of Academics, Business, and Government to Moslem SMEs Development}

This section will describe sinergicity between academics, entrepreneurship, and government with quantitative approach. The analysis used primary data collected from questionnaire spread to the Moslem SMEs businessmen in Malang. Respondents have to answer questionnaire consisted of 17 questions.

\section{Validity Test}

Validity test indicates how far research instruments or indicators are able to measure relatable variables. Validity is indicated by correlation among the score of each indicator with the total of score significant in nature (Sig.<0.05).

\section{Reliability Test}

Reliability test is used to decide consistency of an instrument if used 
Table 2

Reliability Test Result of Research Indicator

\begin{tabular}{clll}
\hline No & \multicolumn{1}{c}{ Indicator } & $\begin{array}{c}\text { Cronbach's } \\
\text { Alpha }\end{array}$ & Description \\
\hline 1 & Individual as the main asset of creative industry & 0.961 & Reliable \\
2 & Technology as a vehicle to realize individual creativity & 0.961 & Reliable \\
3 & Resources (Natural Resources, land) & 0.961 & Reliable \\
4 & Institution & 0.961 & Reliable \\
5 & Financial Intermediary & 0.961 & Reliable \\
6 & The economy creative structure is protected by triple helix & 0.961 & Reliable \\
& interaction as the main actors of creative industry driver. & 0.961 & Reliable \\
7 & Intellectuals & 0.961 & Reliable \\
8 & Business & 0.961 & Reliable \\
9 & Government & Reliable \\
10 & $\begin{array}{l}\text { Intellectuals, Business, and Government as the main driver of } \\
\text { creativity }\end{array}$ & 0.961 & Reliable \\
11 & Tri Bina Cita as Malang Image & 0.961 & Reliable \\
12 & Government support to creative industry & 0.961 & Reliable \\
13 & Entrepreneurs rooted in religion and free from "al- \\
ghayahtubarrirualwashilah" (the end justifies the means) & 0.961 & Reliable \\
14 & An entrepreneur should be able to cultivate Islamic work ethic & 0.961 & Reliable \\
15 & A professional Moslem has to be amanah & 0.961 & Reliable \\
16 & $\begin{array}{l}\text { The properties of Amanah absolutely have to be held by a } \\
\text { Moslem entrepreneur to avoid hurting others. }\end{array}$ \\
17 & $\begin{array}{l}\text { Developing and spreading creative culture to the community } \\
\text { around. }\end{array}$ & 0.961 & Reliable \\
\hline
\end{tabular}

repeatedly. In addition, it is useful to show how far is a test tool can give fixed or consistent information if repeatedly used. A research instrument is said reliable if having Cronbach's alpha value more than 0.60 .

\section{Factor Analysis}

Factor analysis aims to shape factors of research indicators in term of getting a new variable which is simpler or reducing the dimension of research indicators. Table 3 below indicates factor analysis result of those seventeen indicators.

According to Table 3, there are 3 factors shaped by which sample sufficiency or that $\mathrm{KMO}=0.676$ is beyond the limit required by 0.60 , and Bartlett Test of Sphericity is significant (Sig. < 0.05). In other words, the requirement for factor analysis has been met. Of 17 indicators used, those which are dominant in creating the first factor is individual as the first asset of creative industry, technology, institution, triple helix interaction as the main factor of creative industry; intellectuals, business, and government as the creativity main drivers. This is indicated by score factor 1 of those indicators which is higher than others. Based on the indicator dominating factor 1 , it can be said as the variable of creative industry driver subject.

On the other hand, indicators which dominating the second factor are financial intermediary, entrepreneurs rooted in religion, and professional Moslem that has to be Amanah as well as able to develop and spread creative culture to the community around. Of those indicators, it can be said that factor 2 is variable of Moslem businessmen's characteristic.

The dominant indicators that shaping the third factor are resources except for creativity and knowledge (Natural Resources, Land), Government, Tri Bina Cita as Malang image, government support, entrepreneurs cultivate Islamic work ethic, and the properties of Amanah to avoid hurting others. For that matter, the third factors can be called variable of the creative industry supporting. 
Table 3

Factor of Analysis Result and Factor Worth of Research Rotation

\begin{tabular}{|c|c|c|c|c|}
\hline No & Indicator & $\begin{array}{c}\text { Factor Score } \\
1\end{array}$ & Factor Score 2 & $\begin{array}{c}\text { Factor Score } \\
3\end{array}$ \\
\hline 1 & Individual as the main asset of creative industry & 0.727 & 0.353 & 0.351 \\
\hline 2 & $\begin{array}{l}\text { Technology as a vehicle to realize individual } \\
\text { creativity }\end{array}$ & 0.601 & 0.244 & 0.483 \\
\hline 3 & Resources (Natural Resources, land) & 0.339 & 0.180 & 0.781 \\
\hline 4 & Institution & 0.634 & 0.175 & 0.563 \\
\hline 5 & Financial Intermediary & 0.451 & 0.841 & 0.110 \\
\hline 6 & $\begin{array}{l}\text { The economy creative structure is protected } \\
\text { by triple helix interaction as the main actors of } \\
\text { creative industry driver. }\end{array}$ & 0.678 & 0.548 & 0.202 \\
\hline 7 & Intellectuals & 0.853 & 0.248 & 0.154 \\
\hline 8 & Business & 0.643 & 0.487 & 0.436 \\
\hline 9 & Government & 0.477 & 0.324 & 0.735 \\
\hline 10 & $\begin{array}{l}\text { Intellectuals, Business, and Government as the } \\
\text { main driver of creativity }\end{array}$ & 0.881 & 0.095 & 0.320 \\
\hline 11 & Tri Bina Cita as Malang Image & 0.499 & 0.360 & 0.704 \\
\hline 12 & Government support to creative industry & 0.350 & 0.571 & 0.607 \\
\hline 13 & $\begin{array}{l}\text { Entrepreneurs rooted in religion and free from } \\
\text { "al-ghayahtubarrirualwashilah" (the end justifies } \\
\text { the means) }\end{array}$ & 0.293 & 0.882 & 0.267 \\
\hline 14 & $\begin{array}{l}\text { An entrepreneur should be able to cultivate Islamic } \\
\text { work ethic }\end{array}$ & 0.335 & 0.313 & 0.770 \\
\hline 15 & A professional Moslem has to be Amanah & 0.110 & 0.870 & 0.441 \\
\hline 16 & $\begin{array}{l}\text { The properties of Amanah absolutely have to be } \\
\text { held by Moslem entrepreneur to avoid hurting } \\
\text { others. }\end{array}$ & -0.045 & 0.619 & 0.690 \\
\hline 17 & $\begin{array}{l}\text { Developing and spreading creative culture to the } \\
\text { community around. }\end{array}$ & 0.444 & 0.721 & 0.411 \\
\hline & KMO Sampling Adequacy & 0.676 & & \\
\hline \multirow{2}{*}{\multicolumn{2}{|c|}{ Bartlett Test of Sphericity }} & Chi-square & 546.777 & \\
\hline & & Sig. & 0.000 & \\
\hline
\end{tabular}

Source: Researchers, 2017

According to the quantitative analysis using factor analysis method, it can be concluded that through triple helix creative economy model, the correlation between independent variable, government role, academics, and entrepreneur has occurred. In order to deeply analyze the discourse, qualitative analysis with qualitative data was done. The result shows that the role of each actor in the triple helix model is not visible or the sinergicity among the actors is not optimal yet.

\section{Each Actor's Role in the Triple Helix Model}

One thing which needs to be highlighted of each actor's role is entrepreneur representing the industry. Entrepreneurs are
SMEs businessmen engaging in the creative economy. The researchers find that business players have not informed the plan to run their business, but straightly run the execution in which several of them are SMEs who are able to provide additional income, actively participate in the training provided by both government and other parties, have been producing innovative products, and etc.

SMEs entrepreneurs have an important role in the triple helix model such as listed on the research result concerning execution, but it needs to note the deficiency faced by entrepreneurs, such as do not deeply know what organic product is and do not yet optimally use off-line business-based innovations like the use of outlet, house, exhibitions, and other things in trading, and online such as website and social media. For 
that matter, entrepreneur's' role to execute and run their business needs support from other sides to make SMEs more efficient and elevate its economic scale.

In addition to entrepreneurs, academics have also an important role in the triple helix model, in which the role is not far from research and engagement. Academics have performed their role well even though leaving several things to be improved. The main role of the research has been continuously done including the planning stage. In the performance stage, of course, there are training provided for entrepreneurs, but there are also academics who run their business so that indirectly they play a double role which is academics and entrepreneurs at the same time. The result of training and planning stage that has been conducted by academics shows several things need to be repaired to improve SMEs performance, for instance: promotion and packaging process which have to be strengthened and arranged, their role which also helps to communicate among the agents, and other roles in form of equalizing perception among the agents within the triple helix. In addition, it is important to be noted that academics also need to provide training for the entrepreneurs focusing on packaging and promotion.

The government plays an important role in the triple helix model in which its role basically arranges regulation that would eases interaction between entrepreneurs and academics aiming to enhance SMEs performance, except as facilitator between two of them. In practice, government has described well a plan to elevate SMEs quality by describing vision and mission which is expected to be reached through the help of SMEs and academics. One of the methods which can be pursued is through providing training with material strived relevant with the existing problem, in addition to the competent presenter in the engaged field. However, the problem is some SMEs have not felt any synergicity among the factors of productionwhich is, ideas and knowledge- indicating the weak of government to achieve it. In addition, it is also found that the role of government has not optimally become a bridge that connects entrepreneurs and academics. Furthermore, the government database recording related to the needs of UMKM are still not strong/ complete.

Descriptively, it can also be seen that government, entrepreneurs, and academics have not been fully synergized in performing their respective roles to support each other with one goal-that is, being able to advance SMEs that engaging in the creative economy field. Some of the indicators listed are the dual roles executed by government and academics, such as both of them attending training. In addition, there are also double roles of academics and entrepreneurs, and the main problem would be there is no common perception among the three actors caused by the government's role that has not maximally played as the bridge between academics and entrepreneurs. Thus, the key of sinergicity is the communication and coordination among the creative economy caretakers in Malang.

\section{Synergicity Concept of Creative Eco- nomy Product Innovation of Triple Helix Model Modification}

Analysis factor and FGD result show that there are several notes of innovation which can be done in the creative economy model of Moslem SMEs businessmen in Malang. For instance, creative economy has to illustrate added value of benefit for someone else, the needs of including Islamic concept and independence in nature within SMEs, and the last is the needs of equalizing perception among the agents of triple helix model so that they are able to create synergicity among those three actors.

However, there are still several problems to be faced with, namely: (1) the lack of creative, professional and competitive human resources; (2) The lack of quality, heterogeneous, and competitive supporting resources; (3) Competitiveness, developed, and heterogeneous industry structure is not developed yet; (4) Compliance and competitive financing is not available yet; (5) market access openness for creative product; (6) the lack of infrastructure technology availability which is compliance and competitive; and (7) Institutional support which is able to facilitate collaboration between government, community, business world, and academics in the creative economy development which is not optimal yet.

After conducting a research with mixed method, the result shows there is sinergicity conceptual of creative economy product innovation supported by Islamic spiritual capital and independent in nature which has to appear in the moslem SMEs and supported by digitalization and marketing innovation. This is illustrated in Figure 3. 


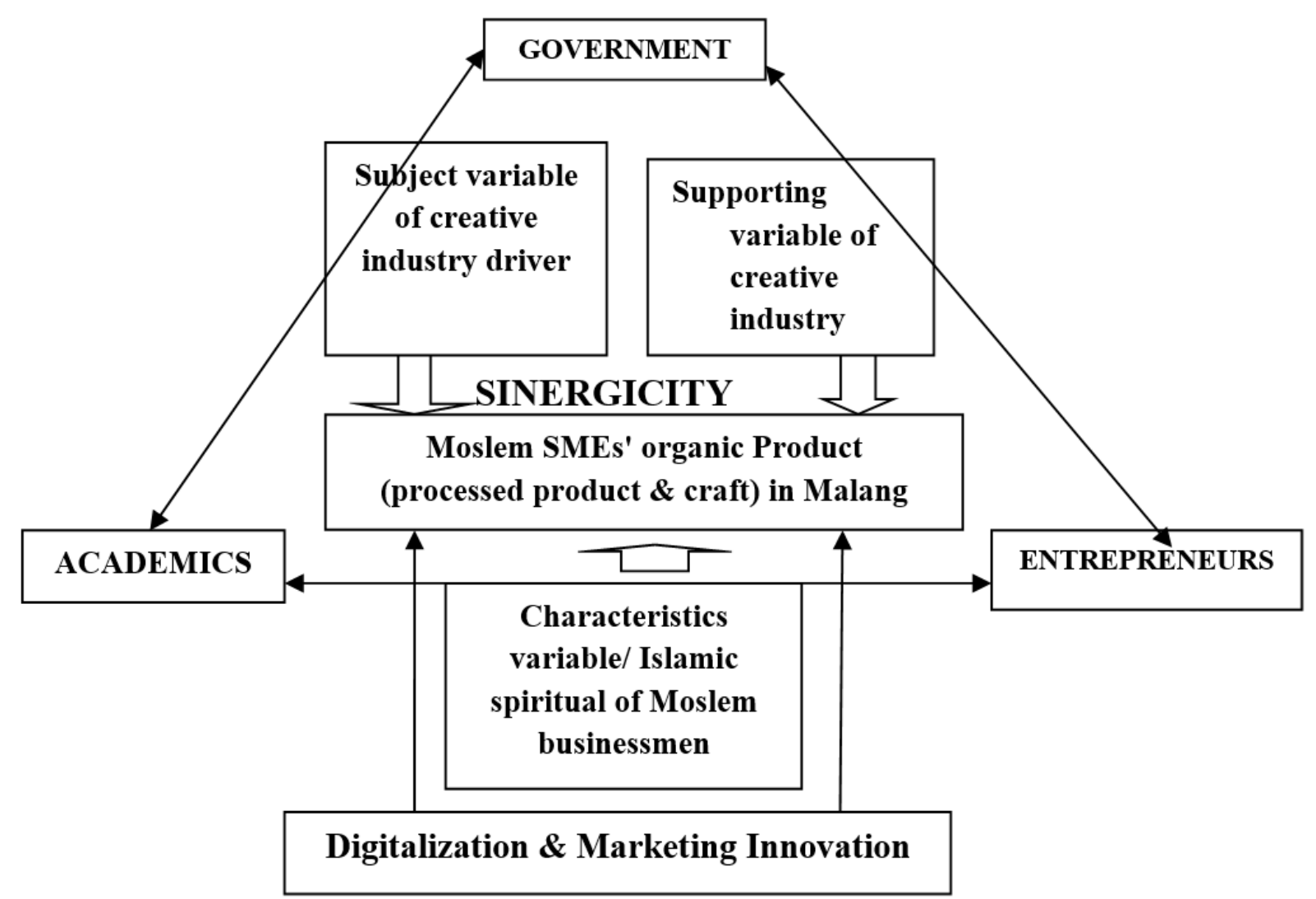

Figure 3. Synergicity Concept of Creative Economy Product Innovation of Triple Helix Model Modification

\section{Conclusion}

According to the factor analysis, agents' synergicity in the triple helix are academics in the university, industry represented by SMEs entrepreneurs, and government, can be led to the three factors of creative industry driver, moslem entrepreneur characteristics, and creative industry support.

Descriptively, it is known that government, entrepreneurs, and academics can not synergize optimally yet due to their respective roles to be able to support each other with one goal-that is, to promote Moslem SMEs engaging in the creative economy. The role in the implementation stage is the existence of double roles performed by government and academics, such as hosting training activities. In addition, there are also double roles of academics and entrepreneurs, and the main problem is there is no common perceptions among three actors caused by the government that has not maximally played the role as a bridge between academics and entrepreneurs.

Triple helix creative economic model can be applied to moslem SMEs' organic product in Malang, but sinergicity does not happen optimally. Based on the observation, communication and coordination among the three caretakers of the creative economy are not intensive yet since there are still overlapping programs among them. It means that there is no intensive communication and coordination yet.

In order to enhance moslem SMEs' persistence in Malang to result in the competitive organic product, it needs training which can sharp Islamic spiritual capitalthat is, prophetic leadership training and management wisdom in term of optimizing sinergicity among the creative economy caretaker of triple helix model. Government, academics, and entrepreneurs in Malang are also need to improve their communication and coordination, especially to support and develop Moslem SMEs' competitiveness green product which required digitalization and marketing innovation.

\section{References}

Arikunto,S. (2006). "Prosedur Penelitian, Suatu Pendekatan Praktek". Jakarta: Rineka Cipta. 
Barbie, E.B.(2012). The Green Economy Post Rio+20.Science, Vol. 338. Pp. 887-888.

Bocella, N. and Salerno,I. (2016). Creative Economy, Cultural Industries and Local Development. Procedia-Social and Behavioral Science, Vol. 223. Pp. 291-196.

Creswell, J.W. (2012). "Educational Research: Planning, Conducting and Evaluating Quantitative and Qualitative Research (4 $4^{\text {th }}$ ed.)".Boston: Pearson Education.

Fitriana, W. (2017). The Role of Triple Helix Actors for Agro Tourism Development in West Sumatera. Mimbar, Vol. 33, No. $2^{\text {nd }}$ ( December, 2017) pp 219-227.

Ghozali,I. (2011). Aplikasi Analisis Multivariat dengan Program IBM SPSS 20. Semarang: Penerbit Universitas Diponegoro.

Henry, C. and Bruin, A.(2011). "Entrepreneurship and The Creative Economy". Cheltenham: Edward Elgar Publishing Limited.

Loiseau, E. (2016). Green Economy and Related Concepts: An Overview. Journal of Cleaner Production, Vol. 139. Pp. 361-371.

Mulyono, S.P. (2014). Sinergitas Penyelenggaraan Pemerintahan Desa Pasca Pemberlakuan UU No. 6 Tahun 2014 Tentang Desa. MMH, Jilid 43 No. 3 Juli 2014

Natario, M.M., Couto, J.P.A, and de Almeida, F.R. (2012). The Triple Helix Model and Dynamics of Innovation: A Case Study. Journal of knowledge-based Innovation in China, Vol. 4 Issue 1. Pp. 36-54.

Pitkanen, K. (2016). What Can Be Learned from Practical Cases of Green Economy? -Studies from Five European Countries. Journal of Cleaner Production 139, Vol. 139. Pp. 666-676.

Rajasekaran, M.R. and Gnanapandithan,
N.A. (2013). Study on Green Product and Innovation for Sustainable Development. Global Journal of Management and Business Studies, Vol. 3 No. 6. Pp. 625632.

Rahmawati,T., Noor, I. and Wanusmawatie, I. (2014). Sinergitas Stakeholders dalam Inovasi Daerah (Studi pada Program Seminggu di Kota Probolinggo (SEMIPRO)). Jurnal Administrasi Publik (JAP), Vol. 2, No. 4, Hal. 641-647

Ranga, M. and Etzkowitz, H. (2013). Triple Helix Systems: An Analytical Framework for Innovation Policy and Practice in The Knowledge Society. Industry \&Hinger Education, Vol. 27. No.3. Pp. 237-262.

Silalahi, U. (2011). "Asas-asas Manajemen". Bandung: Refika Aditama.

Sofyandi, H and Garniwa, I. (2007). "Perilaku Organisasional". Yogyakarta: Graha Ilmu.

Sugiyono. (2010). Metode Penelitian Kuantitatif Kualitatif $R \& D$. Bandung: Alfabeta.

Sugiyono. (2010). Statistika Untuk Penelitian. Bandung: Alfabeta.

Sukhdev, P. (2015). Indonesia green Economy Model (I-GEM). Low Emission Capacity Building Programme: UNDP.

Supranto. (2004). Analisis Multivariat, Arti dan Interpretasi. Jakarta: Rineka Cipta.

Undang-Undang Republik Indonesia Nomor 20 Tahun 2008 Tentang Usaha Mikro, Kecil, Dan Menengah.

Wirda, F., Azra, T., and Herizon. (2016). The Influence of Managerial Competency and External Environment on the Competitive Advantage of a Creative Industries in West Sumatra. Mimbar, Vol. 32, Number 1 (June, 2016) pp 126-138. 